\title{
Determinants of propensity of tertiary agricultural students in Ghana to enter agribusiness as a self-employment venture
}

\author{
E. L. OKORLEY, J.A. KWARTENG \& M. OWENS \\ (E. L. O. \& J. A. K.: Department of Agric. Economics and Extension, University of Cape Coast, Cape \\ Coast, Ghana: M. O.: Formerly with FAO, Accra, Ghana)
}

\begin{abstract}
The study aimed to identify factors that affect the decision of tertiary agricultural students in Ghana to enter agribusiness as a self-employment venture after graduation. The results showed that tertiary agricultural students in Ghana were predominantly males with little or no farming background. They had a rather moderate propensity to enter self-employed agribusiness. The propensity was based on the perception that agribusiness was beneficial, sustainable, and had a bright future. A significant and positive relationship was found between the propensity to enter self-employed agribusiness and availability of inputs, training received by students and supportive policies. However, a significant and negative relationship was found between students' propensity to enter self-employed agribusiness and the desire for other competing enterprises as well as risks and constraints in agribusiness. The most important determinants of the decision of tertiary level agricultural students to enter into agribusiness were found to be attraction to other businesses such as NGOs, nonagricultural manufacturing industries and banks; training received; perceived constraints; and needs for selfemployment in agribusiness. The results indicate that the propensity of agricultural graduates to enter self-employed agribusiness may be increased by (1) making agribusiness attractive by increasing its competitiveness with respect to other enterprises, ( 2) modifying the curricula to make agricultural training at the tertiary level more practical, (3) making it easier to acquire production inputs for agribusiness, and (4) improving the policy environment with supportive policies to minimize risk and constraints in agribusiness.
\end{abstract}

\begin{abstract}
RÉSUMÉ
Okorley, E. L., Kwarteng, J. A. \& Owens, M.: Déterminants de la propension d'étudiants agricoles d'enseignement supérieur au Ghana de s'établir dans les agro-industries comme une entreprise de travailleur indépendant. La recherche était entreprise pour identifier les facteurs qui influencent la decision d'étudiants agricoles du niveau supérieur au Ghana de s'établir dans les agro-industries comme une entreprise de travailleur indépendant après l'obtention du diplôme. Les résultats montraient que les étudiants agricoles de l'enseignement supérieur au Ghana étaient principalement mâles avec peu ou sans expérience d'agriculture. Ils avaient plutôt une propension modérée de s'établir dans l'agro-industrie de travailleur indépendant. Cette propension est fondée sur l'idée que l'agro-industrie est bénéfique, durable et avait un avenir brillant. Un rapport considérable et positif était découvert entre la propension de s'établir dans l'agro-industrie de travailleur indépendant et la disponibilité d'intrants, la formation reçue par les étudiants et les politiques d'appui. Un rapport considérable et négatif était toutefois découvert entre la propension d'étudiants de s'établir dans les agro-industries indépendantes et le désir pour d'autres entreprises en concurrence ainsi que les risques et les contraintes d'agroindustries. Les déterminants les plus importants de la decision d'étudiants agricoles du niveau supérieur de s'établir dans les agro-industries étaient découverts d'être l'attrait aux autres entreprises telles que les ONGs, les industries manufacturières non-agricoles et les banques; la formation reçue; les contraintes remarquées; et les besoins requis pour l'indépendant en agro-industrie. Les résultats indiquent que la propension de licenciés agricoles de s'établir dans l'agro-industrie comme travailleurs indépendants pourrait être augmenté par (1) la transformation d'agro-industrie en la rendant attirante par l'augmentation de sa compétitivité relativement aux autres entreprises, (2) la modification du programme scolaire pour rendre la formation agricole au niveau supérieur plus pratique, (3) la facilitation de l'acquisition
\end{abstract}


Original scientific paper. Received 30 Apr 04; revised 08 Sep 04.

\section{Introduction}

Ghana is endowed with human and natural resources needed for agricultural development. The country has a vast uncultivated land area and many freshwater bodies that can be harnessed to produce enough food to meet local and export demands. It is reported that Ghana is operating agriculturally at 20 per cent of its potential (MoFA, 2002), implying that given the opportunity, it can potentially produce five times what it is producing now. Ghana, therefore, has the potential and a brighter future for agricultural development if provided with the necessary support and resources to overcome the many reported problems faced by the sector. Problems of agricultural development in Ghana are diverse, but one crucial issue of concern is the calibre of people engaged in the sector. Most farmers in Ghana are rural dwellers producing mostly at subsistence levels. These farmers are largely the aged and youth with little formal education who have little or no knowledge of highly productive and scientific agricultural methods. In addition, many rural farmers tend to handle agriculture as part of their culture rather than as a business venture. Such state of affairs do not encourage high productivity and economic development.

The challenge for the agricultural sector in Ghana to respond to growing populations, globalisation and environmental changes is enormous and demands improved farming approaches and involving people who will manage agriculture as a progressive business venture. Siddle \& Swindell (1990) have argued that traditional farming practices must be improved from their subsistence level to include improved scientific methods to cope with the changing demands now. The authors opined that the traditional farming system, characterized by cultural orientation to farming, may partly de resources de production pour l'agro-industrie, et (4) l'amélioration de l'environnement politique avec les politiques d'appui pour réduire au minimum le risque et les contraintes d'agro-industrie.

prohibit improved agriculture in most developing countries. The need is to have motivated individuals or groups of individuals with the technical know-how and the ability to use highly productive technologies available in the system.

A viable option is to get more enlightened young agriculturists who understand current trends and developments in agriculture and the economics of the sector. The assumption is that educated youth are more innovative and more willing to apply modern technologies that have been proven to increase productivity (Rach \& $\mathrm{Na}, 1996)$. This was confirmed empirically by Ryznar (1991) when he found that the efficiency of agricultural production is higher for young and educated farmers than their older and uneducated counterparts.

The government of Ghana, over the years, has made several efforts to encourage the youth to take to agriculture through programmes such as the Educational Reform Programme and the Youth in Agriculture Programme. However, agriculture is still threatened by low participation by the youth, especially secondary and tertiary graduates. Considering the problem of unemployment and the low productivity of the agricultural sector in Ghana, it is a necessary option to encourage tertiary level students of agriculture with the potential to move agriculture forward along a more modern, private and business path to take up farming as a vocation. But to do this, one needs to understand how this category of youth perceive their state of preparedness for agribusiness and the factors that may be affecting their willingness to take up farming as a self-employed venture after graduation.

\section{Objectives of the study}

The main objective of the study was to identify 
factors influencing the propensity of tertiary agricultural students in Ghana to engage in agribusiness as a self-employment venture. Specifically, the study:

1. examined tertiary agricultural students' perceptions of the preparation offered by universities in Ghana in relation to their willingness to enter agriculture or agribusiness as a self-employment venture;

2. identified factors perceived to be influencing the willingness of agricultural students in Ghana for self-employment in agribusiness after graduation; and

3. determined the overall perceived risk and risk factors in self-employed agribusiness.

\section{Materials and methods}

A descriptive survey design was used for the study. Validated questionnaires were used for data collection. A random sample of final year agricultural students at the diploma, bachelor and masters levels constituted the study sample because they had almost completed the agricultural curricula in the universities and could make informed choices on the issue. A total of 247 students comprising 7 per cent masters, 76.4 per cent bachelor, and 16. 6 per cent diploma levels were used for the study. The universities for the study were University of Cape Coast (UCC), Kwame Nkrumah University of Science and Technology (KNUST), and University of Ghana-Legon (UG). They were selected because for several years they had run courses in agriculture and graduated several students. The questionnaires were administered to the students with the help of the heads of department in the selected universities.

Descriptive and inferential statistics were used in describing and summarizing the data. The statistics included percentages, means, standard deviations, and Pearson's coefficients of correlation. The factors influencing willingness to enter self-employed agribusiness were regressed to find which factors best predicted students' propensity or willingness to enter agriculture or agribusiness as a self-employment venture.

\section{Results and discussion \\ Characteristics of respondents}

The results showed that most tertiary agricultural students in Ghana were males $(86 \%)$. They graduated at a mean age of about 29 years with a modal age of 24 years. The universities in Ghana admit only students with either agricultural science or pure science background into their agricultural programmes. The results showed that most students did not have a farming background and resided mostly in the urban and semi-urban communities in Ghana. Most students attended secondary schools outside rural areas. Almost half $(47 \%)$ of the tertiary agricultural students who participated in the study did not choose agriculture as their first choice programme for admission to the university. They indicated that they were pursuing agriculture either because they did not get the courses they wanted $(27.2 \%)$ or they were advised into it by parents and friends (12.5\%). This is consistent with Boakye's (1996) finding that students who attended urban secondary schools were less interested in agricultural occupations than students who attended rural secondary schools.

The findings also confirmed the report of Kwarteng, Zinnah and Ntifo-Siaw (1997) that several youth do not go into agriculture as first choice owing to their negative attitude toward agriculture. Thompson (1981) similarly reported that many people are not willing to be trained and obtain jobs in agribusiness despite its profitability because people perceive agriculture as a menial and less prestigious work. This may partly explain the trend of decreasing interest in agriculture by the youth in Ghana. For instance, the percentage of students who pursue elective agricultural courses at the secondary school level has been dropping steadily. In 1993, 16.04 per cent of all senior secondary students did elective agriculture. This reduced to 14.17 per cent in 
$1994,12.05$ per cent in 1995 , and 10.71 per cent in 1996 (WAEC, 1997). This trend is reflected at the tertiary level, with fewer candidates opting for agricultural courses.

Preparation of tertiary students for vocational agriculture/agribusiness

The findings showed that tertiary agricultural students at the diploma, bachelor and masters levels in Ghana shared similar perceptions about their preparedness for self-employed agribusiness. Students perceived the theoretical aspect of their training as adequate. In contrast, they perceived the practical component of their academic preparation to be inadequate. The perceived areas of best preparation were in vegetable production and use of simple farm tools. The most poorly prepared topic areas were in fish production (aquaculture), non-traditional animal production (grasscutter, rabbit, snail, etc.), and processing and storage of animal products. Other areas listed as poorly prepared were rubber production (latex), woodlot production, coffee production, and maintenance and simple repair of farm machinery.

Students' willingness to engage in selfemployment after graduation

About 42 per cent of the students investigated expressed between moderate to very high willingness for self-employment in agribusiness
(Table 1). The mean value of willingness to engage in agribusiness for the students was high (3.6). However, further analysis showed that only about 20 out of the 42 per cent who showed interest in agribusiness expressed definite willingness for self-employment in agribusiness (Table 1). The students believed that agribusiness had a bright future and was lucrative and sustainable. However, they were unsure they could depend on it or derive the satisfaction they sought. They viewed farming and agribusiness as less prestigious and without the needed policy and extension support (Table 2). This was consistent with earlier findings by Okorley et al. (2001) that extension (contact and training) and policy support (for credit) in general and specifically for women in fish processing was low.

Relationship between respondents' propensity for self-employment in agribusiness and selected factors

Correlation analysis of variables of the study shows that the willingness of tertiary agricultural students in Ghana for self-employed agribusiness was positively related to availability of inputs, university training, supportive policies, theoretical and practical training in animal production, theoretical and practical training in crop production, theoretical and practical training in agricultural mechanization, theoretical and practical training in marketing and accounting

TABLE 1

Level of Willingness of Agricultural Students Regarding Self-employment in Agribusiness

\begin{tabular}{lcc}
\hline Level of willingness & Frequency & Percentage \\
\hline Very much willing & 24 & 9.9 \\
Much willing & 23 & 9.5 \\
Moderately willing & 54 & 22.3 \\
Slightly willing & 68 & 28.1 \\
Not willing & 73 & 30.2 \\
\hline Total & 242 & 100.0 \\
\hline
\end{tabular}

Mean = 3.6, $\mathrm{SD}=1.29$; Scale: $1=$ Not willing, $2=$ Slightly willing, $3=$ Moderately willing, $4=$ Much willing, $5=$ Very much willing 
TABLE 2

Reasons for Willing to Engage in Self-employed Agribusiness by Tertiary Agricultural Students after Graduation

\begin{tabular}{lll}
\hline Reason for willingness & Mean & $S D$ \\
\hline Agribusiness/farming has a brighter future & 3.59 & 1.12 \\
Agribusiness/farming is lucrative & 3.58 & 1.08 \\
Agribusiness/farming is sustainable & 3.53 & 1.03 \\
Agribusiness/farming is dependable & 3.49 & 1.05 \\
Agribusiness/farming is satisfying & 3.40 & 1.01 \\
Agribusiness/farming is prestigious & 2.71 & 1.05 \\
Agribusiness/farming has policy support from government & 2.58 & 0.98 \\
Agribusiness/farming has extension support from government & 2.57 & 0.89 \\
\hline
\end{tabular}

Scale: $1=$ Strongly disagree, $2=$ Disagree, $3=$ Moderately agree, 4= Agree, $5=$ Strongly agree

skills, and practical training in entrepreneurial skills. However, the willingness of tertiary agricultural students in Ghana to enter selfemployed agribusiness is found to be negatively correlated to level of risks in agribusiness, desire for other competing enterprises, and constraints in agribusiness (Table 3). The implications of these are several:

1. An increase in theory and practical training in agriculture at the tertiary level will lead to increased propensity of tertiary agricultural students to enter selfemployed agribusiness.

2. An increase in the perception that agribusiness is better or can compete with other jobs will lead to increased propensity of tertiary agricultural students to enter self-employed agribusiness.

3. An increase in the ease of acquiring production inputs for agribusiness will lead to increased propensity of tertiary agricultural students to enter selfemployed agribusiness.

4. An improvement in the supportive policy environment (e.g. favourable government policies that will improve and facilitate credit acquisition, marketing, and processing of agricultural produce to promote growth) will lead to increased propensity of tertiary agricultural students to enter self-employed agribusiness.

5. A reduction in the level of risks and constraints in agribusiness (e.g. through policy for social security and insurance scheme, and support for partnership arrangement for young agriculturalists in medium to large-scale farming) will lead to increased propensity of tertiary agricultural students to enter self-employed agribusiness.

A regression analysis of the factors related to the propensity of tertiary agricultural students to enter self-employed agribusiness showed that the desire for other competing enterprises, university training (theory and practical), constraints (acquisition of capital, production inputs and land, and storage facilities and market for products), and needs for the venture were the most important predictors (Table 4). Of these, the perception that other competing enterprises are better than agribusiness or farming accounted for 21.4 out of overall 30 per cent of the variation in the propensity to enter self-employed agribusiness (Table 4).

Perceived risk factors in self-employed agribusiness by tertiary agricultural students

An analysis of the information in Table 5 shows that the agricultural students perceived the risk involved in entering self-employed agribusiness 
Correlation Matrix of Factors Related to Willingness (Propensity) of Tertiary Agricultural Students to Go into Agribusiness/Farming

\begin{tabular}{|c|c|c|c|c|c|c|c|c|c|c|c|c|c|c|c|c|c|c|c|}
\hline & A & $B$ & C & $D$ & $E$ & $F$ & $G$ & $H$ & I & $J$ & K & $L$ & $M$ & $N$ & $O$ & $P$ & $Q$ & $R$ & $S$ \\
\hline A & 1.000 & & & & & & & & & & & & & & & & & & \\
\hline B & $-.370 * *$ & 1.000 & & & & & & & & & & & & & & & & & \\
\hline C & .057 & -.044 & 1.000 & & & & & & & & & & & & & & & & \\
\hline D & $-.477 * *$ & $-.323 * *$ & $-.182 * * 1$ & 1.000 & & & & & & & & & & & & & & & \\
\hline E & $.289 * *$ & $-.434 * *$ & $.176^{* * *}$ & $.278 * *$ & 1.000 & & & & & & & & & & & & & & \\
\hline $\mathrm{F}$ & $.317 * *$ & $-.400 * *$ & $.204 * *$ & $.189 * *$ & $455 * * 1$ & 1.000 & & & & & & & & & & & & & \\
\hline G & $.254 * *$ & $-.496 * *$ & .016 & $.216 * *$ & .435 ** & $.235^{* *}$ & 1.000 & & & & & & & & & & & & \\
\hline $\mathrm{H}$ & $.273 * *$ & $-.254 * *$ & .055 & $.193 * *$ & $.330^{* *}$ & $.521 * *$ & $.284 * *$ & 1.000 & & & & & & & & & & & \\
\hline I & $.233 * *$ & $-.175 * *$ & .095 & $.131 *$ & $.225^{* *}$ & $.505^{* *}$ & $.193 * *$ & $.594 * * 1$ & 1.000 & & & & & & & & & & \\
\hline $\mathrm{J}$ & $.185^{* *}$ & $-.131^{*}$ & .023 & $.139 *$ & $.217 * *$ & $.460^{* *}$ & $.146^{*}$ & $.485^{* *}$ & $.674 * *$ & 1.000 & & & & & & & & & \\
\hline K & .123 & $-.133^{*}$ & .089 & .115 & $.254 * *$ & $.462 * *$ & $.246 * *$ & $.429 * *$ & $.465^{* *}$ & $.510 * * 1$ & 1.000 & & & & & & & & \\
\hline L & .068 & -.094 & -.081 & .099 & $.213 * *$ & $.404 * *$ & $.195^{* *}$ & $.427 * *$ & $.467 * *$ & $.547 * *$ & $.734 * *$ & 1.000 & & & & & & & \\
\hline M & $.203 * *$ & $-.212 * *$ & $.202 * *$ & $.175 * *$ & $.323 * *$ & $.565^{* *}$ & $.233 * *$ & $.745^{* *}$ & $.529 * *$ & $.505 * *$ & $.381^{* *}$ & $.430 * * 1$ & 1.000 & & & & & & \\
\hline $\mathrm{N}$ & $.166^{*}$ & $-.202 * *$ & $.231 * *$ & .022 & $.260^{* *}$ & $.554 * *$ & $.198 * *$ & $.552 * *$ & $.715^{* *}$ & $.444 * *$ & $.414 * *$ & $.422 * *$ & $.707 * *$ & 1.000 & & & & & \\
\hline $\mathrm{O}$ & $.145^{*}$ & $-.184 * *$ & $.153 *$ & .034 & $.258^{* * *}$ & $.490 * *$ & $.227 * *$ & $.464 * *$ & $.540 * *$ & $.610 * *$ & $.486 * *$ & $.511 * *$ & $.651^{* *}$ & $.733 * * 1$ & 1.000 & & & & \\
\hline$P$ & $.155^{*}$ & $-.168 * *$ & $.189 * *$ & .097 & $.277 * *$ & $.496 * *$ & $.221 * *$ & $.426 * *$ & $.410 * *$ & $.374 * *$ & $.678 * *$ & $.593 * *$ & $.619 * *$ & $.666 * *$ & $.730 * * 1$ & 1.000 & & & \\
\hline Q & $.134 *$ & -.123 & -.002 & .105 & $.212 * *$ & $.415 * *$ & $.207 * *$ & $.389 * *$ & $.363 * *$ & $.347 * *$ & $.569^{* *}$ & $.718^{* *}$ & $.561 * *$ & $.573 * *$ & $.680 * *$ & $.835 * * 1$ & 1.000 & & \\
\hline $\mathrm{R}$ & .113 & .090 & -.099 & $.169 * *$ & $-.144 *$ & $-.150 *$ & .002 & -.047 & -.204 & .095 & -.007 & .066 & -.052 & -.051 & -.017 & -.045 & -.023 & 1.000 & \\
\hline S & $-.180 * *$ & $.225^{* * *}$ & -.080 & .001 & $-.255 * *$ & $-.250 * *$ & $-.161 *$ & -.121 & -.065 & -.050 & $-.132 *$ & -.116 & -.111 & -.061 & -.804 & $-.210 * *$ & $-.183^{* * *}$ & $.451 * *$ & 1.000 \\
\hline
\end{tabular}

Significant at $5 \%$ level

* Significant at $1 \%$ level

A. Willingness to Enter into Self-employed Agribusiness

B. Risk Factors

C. Age of Students

D. Competing Enterprises

E. Availability of Input

F. University Training

G. Supporting Policies

H. Theoretical Training in Animal Production

. Theoretical Training in Crop Production

J. Theoretical Training in Agricultural Mechanization

K. Theoretical Training in Entrepreneurial Skill

L. Theoretical Training in Marketing and Accounting Skills

M. Practical Training in Animal Production

N. Practical Training in Crop Production

O. Practical Training in Agricultural Mechanization

P. Practical Training in Entrepreneurial Skill

Q. Practical Training in Marketing and Accounting Skills

R. Needs

S. Constraints 
TABLE 4

Regression Results of Factors Related to Willingness (Propensity)* of Tertiary Agricultural Students to Go into Agribusiness/Farming

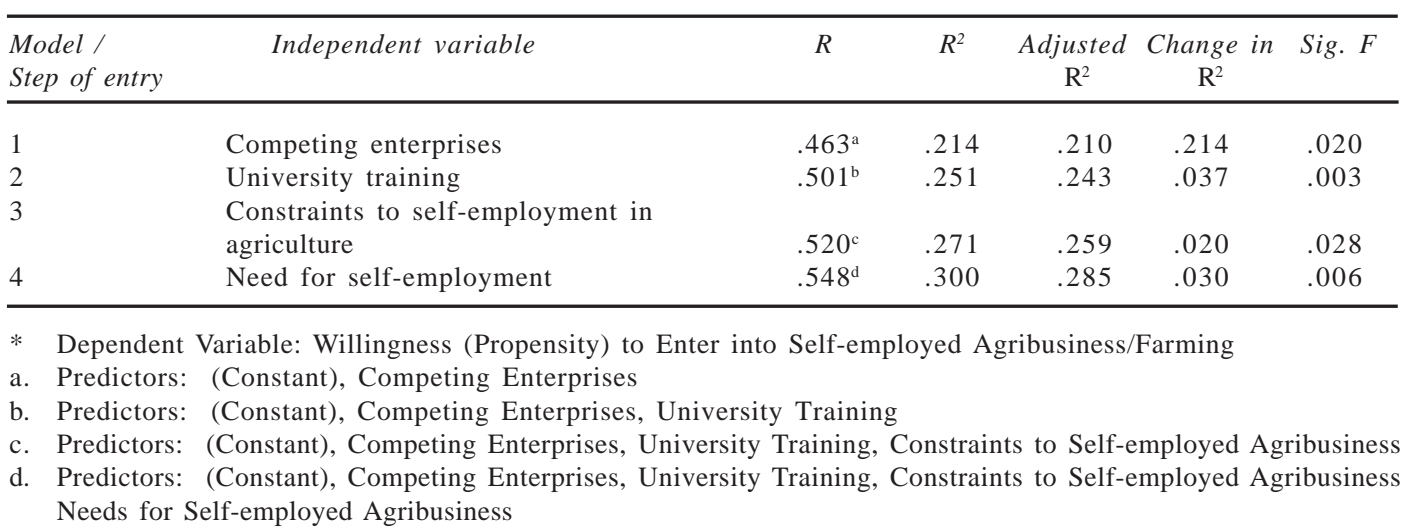

to be high because they registered disagreement with 24 out of 32 risk-related statements.

Table 5 shows that apart from the control of weeds, diseases, and pests that the students considered to be moderately available and accessible, all other factors were considered highly risky to them, especially credit support to manage risk, market competition between agroand imported products, storage facilities for farming, land tenure arrangements, and fluctuating prices for agro-products and services.

\section{Conclusion}

Tertiary agricultural students perceive practical training, necessary for vocation-oriented agriculture and agribusiness, as inadequate in quality of preparation compared to theoretical training. Again, tertiary agricultural students in Ghana perceive their training to be inadequate for going into farming and agribusiness in the following areas: agricultural mechanization, entrepreneurial skills, fish production (aquaculture), non-traditional animal production (grasscutter, rabbit, snail, etc.), post-harvest crop processing, and rubber (latex), woodlot, and coffee production.

The most important factors affecting tertiary agricultural students' propensity to enter agribusiness are attraction to other enterprises, training given to students, constraints and needs. The propensity of agricultural students to enter self-employed agribusiness will increase under the following conditions: (1) making agribusiness attractive compared to competing enterprises, (2) increasing theory and practical training in agriculture at the tertiary level, (3) increasing the perception that agribusiness is better or can compete with other jobs, (4) increasing the ease of acquiring production inputs for agribusiness, (5) improving the supportive policy environment, and (6) reducing the level of risk and constraints in agribusiness.

Tertiary agricultural students in Ghana perceive the risk level in agribusiness to be high because of uncertainties in securing start-up capital, capital credit support, and market for agricultural products. Tertiary agricultural students in Ghana are also strongly attracted to other businesses such as NGOs, non-agricultural manufacturing industries, and the financial institutions (banks).

The following are recommended based on the findings of the research:

1. The study suggests that tertiary agricultural students in Ghana have only a 
TABLE 5

Perceived Risk Factors in Self-employed Agribusiness by Tertiary Agricultural Students

\begin{tabular}{|c|c|c|}
\hline Type of risk & Mean & $S D$ \\
\hline Means of controlling weeds are available & 3.47 & 0.86 \\
\hline Means of controlling diseases are available & 3.28 & 0.82 \\
\hline Means of controlling pests are available & 3.24 & 0.85 \\
\hline Means of controlling weeds are accessible & 3.21 & 0.86 \\
\hline Means of controlling pests are accessible & 2.93 & 0.86 \\
\hline Means of controlling diseases are accessible & 2.90 & 0.83 \\
\hline Market for agro-products/services is accessible & 2.64 & 0.81 \\
\hline Market for agro-products/services is available & 2.61 & 0.80 \\
\hline Transportation facilities for farming/agribusiness are accessible & 2.49 & 0.88 \\
\hline Means of controlling weeds are affordable & 2.48 & 0.91 \\
\hline Transportation facilities for farming/agribusiness are available & 2.44 & 0.91 \\
\hline Opportunity for post-harvest processing is available & 2.40 & 0.94 \\
\hline Prices of agro-products/services are fair & 2.33 & 0.83 \\
\hline Opportunity for post-harvest processing is accessible & 2.31 & 0.87 \\
\hline The rainfall distribution is favourable & 2.29 & 0.81 \\
\hline Means of controlling pests are affordable & 2.27 & 0.80 \\
\hline Means of controlling diseases are affordable & 2.24 & 0.76 \\
\hline The rainfall pattern is predictable & 2.19 & 0.90 \\
\hline The rainfall intensity is always adequate & 2.16 & 0.81 \\
\hline Opportunity for post-harvest processing is affordable & 2.14 & 0.83 \\
\hline It is easy to manage risk in agribusiness/farming & 2.12 & 0.95 \\
\hline Storage facilities for farming/agribusiness are available & 2.07 & 0.87 \\
\hline Transportation facilities for farming/agribusiness are affordable & 2.06 & 0.81 \\
\hline Land tenure arrangements are favourable & 2.05 & 0.85 \\
\hline Storage facilities for farming/agribusiness are accessible & 2.05 & 0.85 \\
\hline There is insurance in farming/agribusiness & 2.00 & 0.97 \\
\hline Credit support to manage risk is accessible & 1.98 & 0.84 \\
\hline Market competition of agro-products with imported products is favourable & 1.95 & 0.79 \\
\hline Storage facilities for farming/agribusiness are affordable & 1.95 & 0.78 \\
\hline Land tenure arrangements are secure & 1.95 & 0.84 \\
\hline Credit support to manage risk is available & 1.87 & 0.83 \\
\hline Prices for agro-products/services are stable & 1.80 & 0.70 \\
\hline Overall mean & 2.37 & 0.45 \\
\hline
\end{tabular}

Scale: $1=$ Strongly disagree, $2=$ Disagree, 3= Moderately agree, 4= Agree, $5=$ Strongly agree

Note: The smaller the mean on the agreement/disagreement scale, the higher the risk level and vice versa

moderate propensity to enter self-

employed agribusiness and 20 per cent have the strong desire to go into it. It is important for government and community development organizations to take advantage of this positive attitude to support the few who want to enter it.

2. The Government of Ghana (GOG) has a fundamental role to play to promote and facilitate the willingness of tertiary agricultural students in Ghana to go into agribusiness. The reform of policy in the 
country needs to be facilitated to provide credit support, market for agricultural products, storage facilities, land and good prices for agricultural products.

3. The GOG must encourage tertiary agricultural students to go into agribusiness in a more professional and business way to make it more profitable, thereby changing the negative attitude toward it in relation to other jobs.

The GOG can achieve this through:

i. Acquiring land and distributing it to agricultural graduates who are willing to go into farming at a low rent.

ii. Encouraging agricultural graduates to form business groups to share risk and access loans as a group. Commercial banks find it more secure to advance loans to groups than to individuals.

iii. Instituting a revolving fund for specialized farmer groups from which agricultural graduates can source capital at an economically low interest rate to establish and maintain their agribusiness.

iv. Improving the agribusiness environment; for example, in capital intensive agribusiness ventures taken by agricultural graduates, it may be important to allow an initial tax-free period or other similar arrangement to ensure that the ventures are established firmly.

v. Encouraging production techniques and value addition that make locally produced goods from agribusiness competitive on the local and international markets.

vi. Regulating the importation of agricultural products that are produced in Ghana to ensure competitive market for agricultural producers.

vii. Promoting public-private partnerships by reconstituting the Ghana Food
Distribution Cooperation and increasing private participation to buy and store excess agricultural produce in bumper seasons to ensure good and stable prices for agricultural products all year round.

viii. Creating the enabling policy and business climate to attract agroprocessing industries into the country to absorb excess agricultural produce to create market and price stability for agricultural produce.

4. Tertiary agricultural institutions in Ghana should revise and reform their agricultural curricula to make them more responsive to the agricultural needs of the country. The trend now is scientific private-led agribusiness to sustain Ghana's economy. The curricula of tertiary agricultural training institutions can be improved to prepare students adequately for agribusiness by:

i. Giving students more practical training through the project approach method of teaching, student attachment programmes, class field experiments, and field trips to enable them to have experiential understanding of the input-output relationships and management in agribusiness.

ii. Emphasizing farm mechanization and entrepreneurial skill development besides fish production (aquaculture), non-traditional animal production (grasscutter, rabbit, snail, etc.), processing and storage of animal products, rubber production (latex), woodlot production, post-harvest crop processing, and coffee production in the curricula.

5. The GOG should do more to provide the basic needs of the universities in infrastructure and funding to run practical lessons. 
6. University lecturers should be encouraged to write vocationally oriented textbooks that will promote agribusiness.

\section{REFERENCES}

Boakye, M. B. (1996) Vocational interest of students in some selected Ghanaian Junior and Senior Secondary Schools (unpublished M Phil Thesis). University of Cape Coast, Ghana.

Kwarteng, J. A., Zinnah, M. M. \& Ntifo-Siaw, E. (1997) Status and constraints of extension training in Africa-An African view . Paper presented at the Joint Workshop on Extension Personnel Training in Africa and 3rd Informal Consultation of International Supporters of Agricultural Extension Systems in Africa, 19-24 October 1997. University of Cape Coast, Cape Coast, Ghana.

MoFA (2002) Agricultural Extension Policy. Ministry of Food and Agriculture: Directorate of Agricultural Extension Services, Accra, Ghana: Retrieved October 15, 2003, from http://www.gtz.de/ agriservice/download/extensionpolicy-ghana.pdf

Okorley, E. L., Zinnah, M. M., Owens, M. \& Mensah, A. O. (2001) Women in agro-processing in Ghana: A case study of the state of small scale fish smoking in the Central Region of Ghana. Proceedings of the Association for International Agricultural and Extension Education (AIAEE) 17th Annual Conference 'Emerging Trends in Agricultural and Extension Education'. April 4-7, 2001, Baton Rouge, Louisiana, USA. 407 pp.

Siddle, D. \& Swindell, K. (1990) Rural change in tropical Africa from colonies to nations-states. Oxford: Basil Blackwell.

Thompson, A. R. (1981) Education and development in Africa: An introduction to the study of the role education may play in national development intended primarily for teachers in training and in service. London, Macmillan Publisher.

Rach, D. T. \& Na, I. S. (1996) Variables associated with adoption and non-adoption of pesticides by plantain farmers in the Dominican Republic. In Conference Papers, 12th Annual Conference (AIAEE).

Ryznar, J. (1991) Factors determining the efficiency of Spread-Consultancy provided by agricultural instructing services in individual farms. Wroclaw (Poland) Wydawnictwo Akademii, Rolniczejwe Wroclawiu.

WAEC (1997) West African Examinations Council Report. Accra, Ghana. 